\title{
Long Noncoding RNA DLEUI Aggravates Glioma Progression via the miR-42I/MEF2D Axis [Retraction]
}

Feng L, He M, Rao M, Diao J, Zhu Y. Onco Targets Ther. 2019;12:5405-5414.

The Editor and Publisher of OncoTargets and Therapy wish to retract the published article. The authors initially raised concerns that two of the glioma cell lines (LN229 and A172) reported in the study had been contaminated with HeLa cells. The authors advised that they were unable to provide the original raw data for their study and thus were unable to verify its findings. The authors also advised the study did not have approval from the China-Japan Union Hospital of Jilin
University ethical committee prior to commencement. This is despite a statement within the article stating that approval had been given.

Our decision-making was informed by our policy on publishing ethics and integrity and the COPE guidelines on retraction.

The retracted article will remain online to maintain the scholarly record, but it will be digitally watermarked on each page as "Retracted".

\section{Publish your work in this journal}

OncoTargets and Therapy is an international, peer-reviewed, open access journal focusing on the pathological basis of all cancers, potential targets for therapy and treatment protocols employed to improve the management of cancer patients. The journal also focuses on the impact of management programs and new therapeutic agents and protocols on patient perspectives such as quality of life, adherence and satisfaction. The manuscript management system is completely online and includes a very quick and fair peer-review system, which is all easy to use. Visit http://www.dovepress.com/ testimonials.php to read real quotes from published authors. 